COMPARATIVE CHEMICAL-MINERALOGIC INVESTIGATION OF FIVE WESTERN ALPINE LHERZOLITE COMPLEXES

W. G. Ernst (Department of Earth and Space Sciences; Institute of Geophysics and Planetary Physics, University of California, Los Angeles, CA 90024)

\title{
Petrotectonic Setting:
}

The Alpine orogenic belt apparently marks the site of convergent 1ithospheric plate motion during Late Mesozoic and Early Cenozoic time. Prior to this complex event, Early Mesozoic rifting evidently resulted in generation of the Jurassic-Early Cretaceous Tethyan basin which separated the northern and western European plate from the more southeasterly South Alpine plate. The hypothesized onset of rapid convergence in Late Cretaceous time caused consumption of the intervening sea floor and mantle underpinnings along a southward and eastward dipping subduction zone (=Alpine Suture), and seems to have culminated in the collision of both northern and southern continental crust-capped sections and a partial subduction of the European sialic margin.

Ultramafic rocks of the Western Alps appear to reflect several different lithologic entities. (1) A first group represents pre-Jurassic mantle fragments which constitute an in situ portion of the terrane subjected to the multistage Alpine tectonic and metamorphic events. An example may be the Malenco complex; this mass exhibits the effects of Alpine deformation and metamorphism(s). (2) A second group consists of peridotites which lie structurally beneath the continental (locally oceanic) crust capping the Southern Alpine plate. The subcontinental Finero body, terminated on the northwest by the Insubric Line, is of this type inasmuch as it clearly occupies a basal portion of the southern continental crust-capped plate; its age of recrystallization appears to be pre-Mesozoic. Other peridotite massifs of unknown age may have formed beneath more oceanic portions of the South Alpine plate and were subsequently transported north and west during closure of Mesozoic Tethys. (3) A third ultramafic group is ophiolitic and is associated with the Mesozoic metasedimentary cover of the more southeasterly portions of the Tethyan-European plate. Typical examples include intensely serpentinized peridotites of the Zermatt-Saas area east of the Dent Blanche nappe and the eclogite-bearing Voltri serpentinites of the Ligurian Alps. (4) Yet a fourth variety of ultramafic body in the Alps consists of peridotite derived from deep within the upper mantle and emplaced tectonically within the metamorphosed section of continental crust during or after most of the Alpine age recrystallization had occurred. Although its origin is still uncertain, the Alpe Arami garnet peridotite may belong to this group.

\section{Rock and Mineral Chemistry:}

Petrochemical study has been undertaken of five peridotite bodies exposed at Alpe Arami in southern Switzerland, and at Finero, Balmuccia, Baldissero and Lanzo in northwestern Italy. The Alpe Arami mass has been tectonically emplaced within the in part subducted, more northerly European-Tethyan 1ithospheric plate, whereas the other four ultramafic masses represent portions of the nonsubducted South Alpine plate.

The eighty samples examined are chiefly lherzolites, but a few are clinopyroxene-bearing harzburgites, olivine websterites or clinopyroxenite. Alpe Arami peridotites locally contain garnet; in contrast, the South Alpine lherzolites are spine1- \pm plagioclase-bearing. All masses display strain 
effects such as bent lamellae in pyroxenes, gradational or sectoral optical extinction, and minor recrystallization. Twenty-four bulk XRF analyses demonstrate that the investigated rocks closely match pyrolite composition, but are slightly impoverished in alumina. Normative olivines of all analyzed specimens have $\mathrm{Fa}$ contents ranging between 8 and 10 mole percent. Electron microprobe analyses for 26 olivines, 27 orthopyroxenes, 23 calcic pyroxenes, 3 garnets, 18 spinels, 3 plagioclases, 13 calcic amphiboles, 2 chlorites, and 2 phlogopites were performed. Phases in a particular sample are remarkably homogeneous, an observation consistent with an inferred close approach to chemical equilibrium.

Apparent temperatures of equilibration for opx + cpx-bearing peridotites were determined employing a variety of methods. Average values in ${ }^{\circ} \mathrm{C}$ and one standard deviation for each body are:

\begin{tabular}{|c|c|c|c|c|c|}
\hline Area & $\begin{array}{l}\text { Mysen } \\
(1976) \\
\end{array}$ & $\begin{array}{l}\text { Lindsley } \\
\text { \& Dixon } \\
(1976) \\
\end{array}$ & $\begin{array}{l}\text { Wood \& } \\
\text { Banno } \\
(1973) \\
\end{array}$ & $\begin{array}{l}\text { Mysen \& } \\
\text { Boettcher } \\
\text { (1975) }\end{array}$ & $\begin{array}{l}\text { Grand } \\
\text { Average }\end{array}$ \\
\hline Alpe Arami & $921 \pm 58$ & $1009 \pm 87$ & $1026 \pm 44$ & $908 \pm 56$ & $966 \pm 78$ \\
\hline Finero & $848 \pm 32$ & $785 \pm 50$ & $966 \pm 27$ & $972 \pm 81$ & $893 \pm 94$ \\
\hline Balmuccia & $966 \pm 43$ & $960 \pm 75$ & $971 \pm 41$ & $996 \pm 44$ & $973 \pm 50$ \\
\hline Baldissero & $1002 \pm 29$ & $1026 \pm 45$ & $973 \pm 25$ & $1013 \pm 32$ & $1002 \pm 37$ \\
\hline Lanzo & $1018 \pm 56$ & $1044 \pm 88$ & $1049 \pm 43$ & $1165 \pm 72$ & $1069 \pm 85$ \\
\hline
\end{tabular}

Pressure estimates for the Alpe Arami mass depend critically on the method used, but cluster about $40 \pm 10 \mathrm{~kb}$; South Alpine 1herzolites appear to have recrystallized within the range $5-20 \mathrm{~kb}$. Apparent physical conditions of origin are shown in Fig. 1.

\section{Interpretations:}

Geologic and petrologic relationships demonstrate that, with the possible exception of the Finero complex, all the studied peridotites are bounded by faults or sheared contacts, hence were transported from elsewhere and tectonically emplaced in their present (deep) crustal surroundings. All five bodies exhibit mantle mineralogies and bulk rock chemistries. The phase assemblages indicate final apparent equilibration temperatures of about 900$1100^{\circ} \mathrm{C}$, also reflecting a mantle origin. Pressure evaluation is more difficult, but clearly the Alpe Arami garnet 1herzolite came from depths exceeding 70, and probably approaching $150 \mathrm{~km}$. In contrast the four investigated spinel peridotites of the Southern Alpine plate appear to have equilibrated at shallow depths within the uppermost mantle.

Subsequent to their crystallization, transit towards the present crustal levels resulted in solid-state reequilibration; in some cases partial fusion accompanied this rise, producing mafic dikes and layers, especially in the Lanzo and Finero massifs, to a lesser extent in the Balmuccia complex, and perhaps only incipiently at Baldissero. If the grand average apparent temperature, $893 \pm 94^{\circ} \mathrm{C}$, determined in the present study for two Finero samples closely approaches the true value, then partial melting of this largely recrystallized massif must have required at least a moderate activity of $\mathrm{H}_{2} \mathrm{O}$. In contrast, the $\mathrm{P}-\mathrm{T}$ path followed by the ascending Alpe Arami body certainly did not intersect the peridotite solidus, as indicated by the lack of partial fusion phenomena. Hornblende may be part of the primary assemblage in some of the South Alpine peridotites, whereas it is definitely later than the garnet 


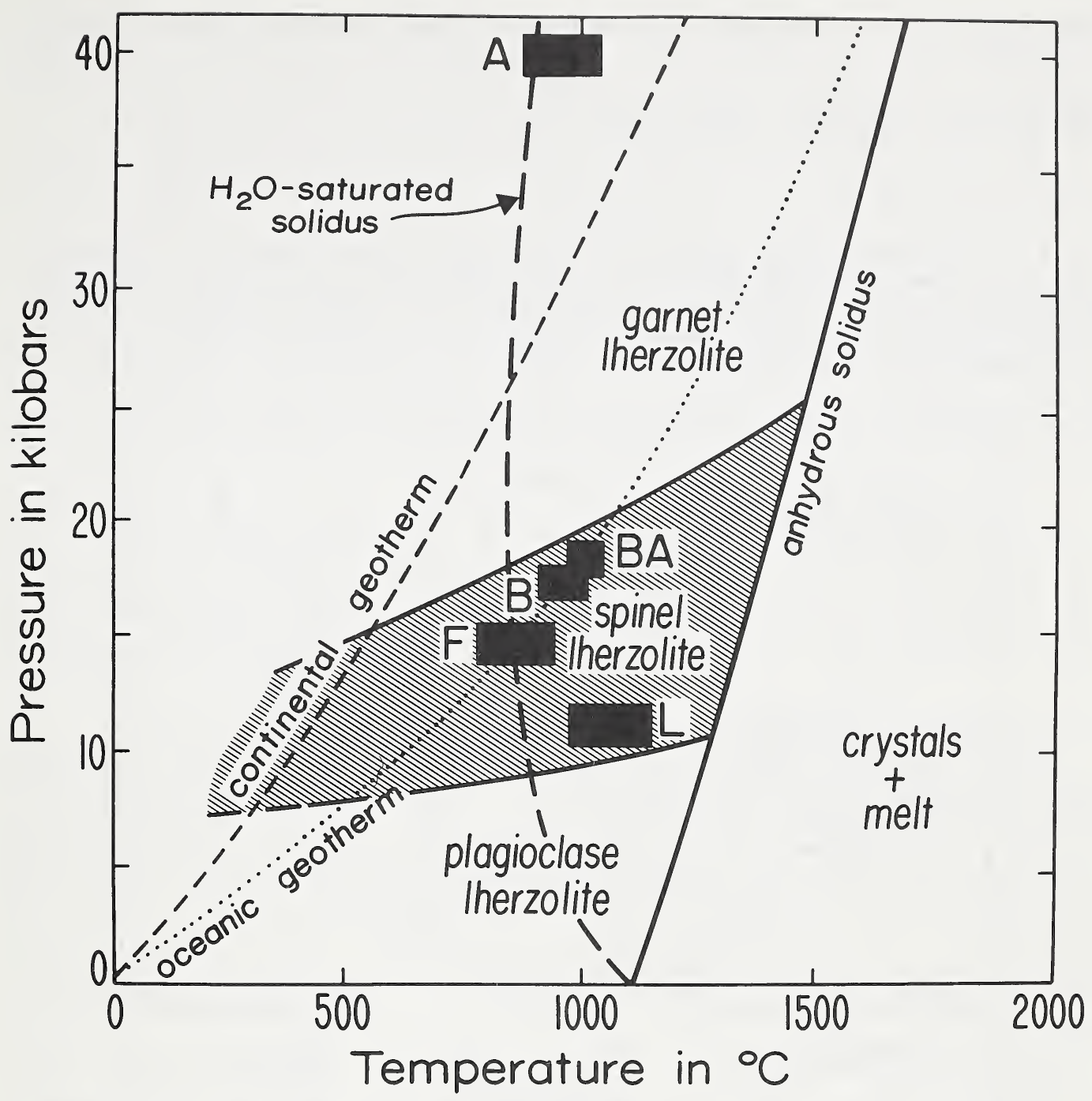

Therzolitic phase compatibility at Alpe Arami. Judging from the calcic amphibole high-pressure stability limit of about $20-25 \mathrm{~kb}$, even at $\mathrm{P}_{\text {fluid }}=$ $P_{\text {total, }}$, the Southern Alpine peridotites must have crystallized at somewhat shallower depths than the Alpe Arami body.

Referring to Fig. 1, it seems likely that the garnet 1herzolite now exposed at Alpe Arami was derived from a portion of the deep upper mantle characterized by a subcontinental geothermal gradient; the manner in which this small, dense mass was incorporated in the northern European plate is perplexing. The Southern Alpine spinel lherzolites, on the other hand, seem to have formed or recrystallized in much shallower, higher heat flow environments (i.e., typified by suboceanic geothermal gradients). Perhaps these latter peridotites represent fragments of mantle material derived from the northerly termination of the South Alpine 1ithospheric plate, where continental crust was thin--as at Finero--or nonexistent. Their high-temperature, low-pressure mineral assemblages seem to indicate a history which involved reequilibration under physical conditions more appropriate to an oceanic rather than a continental thermal regime, and to preclude an origin well within the continental crust-capped South Alpine plate. 